\title{
IS THERE A CLASSICAL SOLUTION FOR A CONTEMPORARY PROBLEM?
}

\author{
Nicolae MOROIANU ${ }^{a 1}$, Daniel-Ștefan BELINGHER ${ }^{b}$ \\ ${ }^{a}$ Bucharest University of Economic Studies, \\ b Hyperion University Bucharest,
}

\begin{abstract}
This paper presents the connection between the main schools of economic thoughts, which explain the role of governmental intervention in the economy and the importance of wages, as countercyclical stabilizers in an economic system. This work aims to look into the economic European situation during the period which precedes the beginning of the current sanitary crisis, in light of empirical analysis. This analysis uses the corresponding data for two years, 2018 and 2019 and includes a series of activity business sectors considered to be relevant (for instance public administration and HoReCa/hospitality, in the light of the impact the sanitary crisis had upon them). The results of this sectoral analysis have as scientific objective the study of the relationship between the evolution of the staff expenditures in the public administration and the evolution of the Gross Domestic Product, emphasizing the level of correlation between these two. Into the assessed context, the research question remains open: if - in the event of a certain reduction of the staff expenditures from the state budget, in order to reach a balanced budget - this could be a real solution (even if only an emergency solution) since there is a high risk of recession; or even more - could be the trigger factor in driving the Romanian economy to a vicious cycle of austerity.
\end{abstract}

KEYWORDS: state budget, expenditures, governmental intervention, countercyclical stabilizers, recession.

DOI: $10.24818 / \mathrm{IMC} / 2021 / 05.18$

\section{EPISTOLOGICAL REMARKS AND THE CARE FOR HISTORY}

The controversies and the fascination related to what could represent a driving force for the aggregate demand and for consumption (or, regarded in the mirror - for savings) had an important role in the recent history of economics, even if many times only through the epistological positioning of the economists. The classics helped to lay the foundation of the monetarism since the work of John Maynard Keynes was the cornerstone in understanding the Great Depression from 1929 - 1933 and the way in which the world had changed at the beginning of a new century; also, the fundamental work of Keynes was an important evolution point in Microeconomics history, as a branch of Economics, as we will see in the current section of this paper.

\footnotetext{
${ }^{1}$ Corresponding author. E-mail address: nicolae.moroianu@economie.ase.ro
} 
All these intellectual disputes started from a series of open debating subjects of economics, such as the control of cyclicality of the economy or elimination of vulnerability to shocks, all facets of economics, which in fact mimic the vulnerabilities of life in natural conditions.

Imminence of a disaster, even if on a short term one, helped giving birth of some questions which target the way of action - on the one hand - at the national scale of the state / governments, or at a bigger scale - of the supranational entities (like European Commission or even World Health Organisation, in the current context of the pandemic caused by the infection with SARS-CoV2 virus), during crisis situations or increased uncertainty.

What makes the difference between Keynes and the economists of the time was quite the variant he offered as solution to the economic decision makers, in the fight with the economic crisis: action through state intervention, as compared with the non-action, specific to the 'laissez-faire' claimed by the classical economists. This action has the main role to restart the economy through the boosting of the aggregate demand. Thus, this first part of the present paper has the objective of mapping the main schools of economic thought and the perspective towards a potential threat, meaning an economic recession.

Therefore, compared with Say's Law, which considers the supply as the most important and decisive factor of the functioning of a macroeconomic overall - 'the supply creates its own demand' - Keynesian policies focus on the stimulation of the aggregate demand, this representing the main catalyst of the economic recovery during crisis periods. In other words, 'the demand creates its own supply'. To reach this point into the construction of his fundamental work, The General Theory of Employment, Interest and Money (1936), J.M. Keynes took into consideration one of the truths of his time, i.e. the fact that during the Great Depression at the beginning of 1930s the capacity of the economy to supply goods and services was not dramatically reduced.

Keynes, together with those who aligned themselves to his work, brought the maximum employment level into the lights. In the United States, unemployment raised by $20 \%$, but the number of workers remained relatively constant. A similar course had the production facilities: even if many factories were closed, the production facilities remained in the same places where they had been initially installed and they had not completely disappeared. Thus, resulted in a recessionary gap (the economy produces less than its maximum capacity) not because it cannot produce more with the current facilities, from the point of view of the production factors per se (capital, woks, and technology), but rather because there is no demand to offer a mercantile stimulus to the companies so that these to continue the production at the levels before the economic crisis. Therefore, the demand becomes the most important element which composes GDP.

At the other pole of the spectrum of thinking there is the Austrian school, which proposes a theoretic model of the business cycles and a simple explanation for the deviation from the main trend of the economy: the economic expansion is sustainable only if this appears as a result of increased investments/savings $(\mathrm{S}=\mathrm{I})$, while the economic increase resulted after an expansion of crediting (most of the times, a sharp rise, in the boom phase), will lead to an inconsistency of the economic sustainability (Tempelman, 2010). This inconsistency is caused by the inefficiency of capital allocation, which in the end will culminate with the bubble burst, created by the repositioning towards capital goods, instead of consuming goods. The same mechanism also operates during the periods of economic decline; credit/debts expansion does not function for a healthy economic recovery, on the contrary, it will postpone it, as it keeps 'in intensive care' those 
businesses that are not any more cost-effective, as well as other inefficient forms of capital allocation.

According to the theory of the economic cycles, described by the Austrian school, when credit is created artificially and the credit volume exceeds the structural capacity for savings of a society, the financial intermediaries end up borrowing money at an interest rate which is under the level where the demand and the supply meet (Tempelman, 2010). The result will consist of a distorted inclusion of the information contained in the prices of the market, leading towards inefficient, subsequent allocations of the capital.

One of the main exponents, considered by economic history an advocate of the freedom of the markets, Milton Friedman himself, opposed this thinking pattern. He did not consider the economic cycles to be a faithful representation of reality, through which could have been explained in real terms the evolution of the economic system. He only believed in the existence of two typologies of economic theories, i.e. good and bad (drawing here a parallel regarding the differences between the Austrian School and Chicago School), the good ones being described precisely by the explanatory and predictive strength of the generated data.

In securing this belief, Friedman's epistemological affiliation can intervene, related to the economy. Thus, economic science should have a 'positive' approach, inclined to explain what it is, rather than a 'regulatory' approach, with the role to establish a set of clear norms, regarding what should be (Friedman, 1966).

Also, Friedman actually considered that 'the art of economy' and the normative economy, too, should be founded on the positive economy; any conclusion related to the politics which are to be implemented, 'that rather should be done one thing instead of other' can only derive from this. The main characteristic of the positive approach in economics is represented by the independence of 'any ethical position or normative judgment' (Friedman, 1966). Even if through the normative approach itself, the economy remains dependent on the positive approach, because the observations on the process or studied phenomenon may appear eminently following a prior prediction, which falls into positivism.

It is noted that the scientific perspective of the one who was named 'the father of monetarism' is eminently different from the one of J.M. Keynes, who had as final objective a trial to theoretically substantiate the use of the economic policies by the governments, thus suggesting ways for optimal implementation of these policies - which otherwise would fall into the pattern of the 'normative' economy.

Paul Samuelson was the one who brought in the mid 1950s consensus between the approach of the classical economists and Keynes 'position regarding the action of State in economy when there is an eminence of a crisis, and even further, of a recession, through neoclassical synthesis. Thus, in the short term, the State interventions in markets is the one which will lead the economic system towards a steady state in the long run - since the markets are not capable themselves to ensure a full employment (Landman, 2014). Neoclassical synthesis was the one which integrated - logically and coherently-Keynes' position in the context of the markets' freedom and offered the possibility of using Keynesian politics by the governments of the developed economies, during the period following the Second World War (Landan, 2014). After the governmental intervention and 
mapping a route towards the balanced area, the markets will function independently of other interferences, till the next economic crisis.

Later, during the mid-1980s, there were voices that claimed that State intervention is useless. Edward Prescott was the most known voice, as he developed the theory of the real business cycle (Real Business Cycle - RBC). The main thesis of this theory consists in the functioning of the economy at the level of full employment, the economic fluctuations being determined by exogenous shocks, like the increase of the oil prices in the 1970s, or the changes in productivity level at the beginning of 1990s (Stiglitz and Walsh, 2002).

Thus, the markets can adapt themselves rapidly to the new conditions, the prices, and the wages being flexible enough to reach a new level of full employment. The main disadvantage generated by the governmental intervention consists in the identification and acknowledgment of the problem, a process which is more difficult from the time duration point of view, as compared to the automatic and direct response of the markets.

In fact, $\mathrm{RBC}$ has also as subsequent purpose the approach of a problem raised quite recently in the field of economic science by the New Classics, through the voice of a Nobel laureate, Robert Lucas (1976); his criticism relates to the adequate evaluation of the impact of macroeconomic politics, due to the fact that 'the forecasts of the economists generate a response which cancels their efficiency' (Taleb, 2007). At the same time, Lucas's criticism brings into discussion the way of constructing the macroeconomic models, due to the fact that they do not incorporate information rendered by the fundamentals of the microeconomic models.

Thus, into the economic field cannot be correctly evaluated the accuracy of the forecast, as it happens in other scientific areas. Therefore, RBC theory does not consider the monetary shocks and nor the changes in population expectations as factors that can substantially influence the business cycles, hence rejecting the Keynesian approach, but also the monetarism, with the same measure. However, in spite of this rejection of the RBC economists, we can consider both Keynes interventionism and monetarism extremely important pillars in the development of the modern macroeconomy.

In response to the New Classical School of economic thinking, the appearance of the term New Keynesian School (New Keynesian), was somehow inherent in the middle of the 1980s, according to Colander (1992). The main characteristic of the new Keynesian approach was that it focussed on some problems/fundamental hypotheses which have been appropriated by the New Classical School and used in the process of formation of theories. Specifically, two work hypotheses of the New Classics have been targeted: the first one - regarding the existence of a unique general equilibrium and the second one - regarding the fact that it is not necessarily required to have solid macro fundamentals to run in parallel with the information offered by the microeconomic assumptions, according to the same Colander (1992). Also, Colander (1992) summarizes the debate between the New Keynesian School and Neo-Keynesians based on two fundamental research questions:

a) How can an economy can get blocked at an underemployment level, from the labor market point of view?

b) Which is the role of wages and of the prices rigidity within the thinking/research process of the macroeconomists? 
At the first question, the answers of the two economic schools of thought which had Keynes' work as a source of inspiration are somehow similar: both the representatives of Neo-Keynesians and the representatives of the New Keynesians School believe that equilibrium of the economy which is at an underemployment level can exist only if the wages and the prices are not perfectly flexible, but the New Keynesians do not consider this to be a question worthy to be introduced in the substantiation of the research. Thus, the answer of the two schools of thought at the second question will be totally different: Neo-Keynesians are preoccupied with the problem of wages and flexibility of the prices, while the New Keynesian School is focused more on general matters of coordinating the failures and inefficiencies (Colander, 1992).

As we could see in the first part of this work, we reviewed the main schools of economic thoughts and the variables targeted by each of them in solving crisis situations or recessions. These theories have as central point either J.M. Keynes approach or take Keynes'theory as a reference; in this respect, it is relevant Hicks' work (1937), which is considered to be the starting point in the dichotomy between the classical macroeconomists and the followers of the English economist (Keynes). Lawrence Klein (1956) considers Keynes' contribution to be a 'macroeconomic revolution', with the role of giving a better understanding of the economy, in its way to reaching a full status as Science.

\section{THE RESEARCH METHODOLOGY AND THE MILESTONES}

Starting from the last decades' evolution of the main economic schools of thought in the postKeynes era, the purpose of this section is to establish the conceptual framework of analysis, as well as the further route (road-map) of the analysis. From the point of view of the economic school of thought, the analysis framework used in this paper will be Neo-Keynesian. The analysis comprised in this paper uses statistical data taken from verifiable public sources (for instance: Romanian National Institute of Statistics).

We turned to Neo-Keynesians and to their specific economic vision due to their concern regarding wages' evolution as a variable which has an explanatory and predictive power within the economy, as Colander (1992) described, and the analysis scenario will be of type AD-AS (Aggregate Demand - Aggregate Supply). Further, this model will be presented, i.e. AD-AS model, as it can offer an 'a starting point for solid analysis, as compared with more recent models offered by the New School Keynesian or by the RBC theory - models which came to dominate the modern macroeconomy' - as Krishna and Skott (2005) noted.

Briefly, the methodological framework of the model AD-AS divides the economy in two: the part referring to demand (demand side) and the part referring to the supply (supply side), and examines the interaction between these two using account identities, equilibrium conditions and behavioural and institutional equations', as described by Krishna and Skott (2005). As its name reveals, the part referring to demand examines the factors which have connection with the demand of goods and the demand - supply of assets. The part related to the supply side studies the supply and the way the price is formed on the market, as well as the factors which influence the market. The model is based on two conditions for reaching the balance and these are: 


$$
\begin{gathered}
Y=C+I+G \\
M / P=L
\end{gathered}
$$

Where: $\mathrm{Y}$ is the real production (or GDP), $\mathrm{C}$ is the real consumption, I represents investments and $\mathrm{G}$ represents government spending.

For the second equation, $\mathrm{M}$ is the money supply, $\mathrm{P}$ is the level of prices, and $\mathrm{L}$ is the real demand for currency. Besides these two equations, the model is completed by a set of six behavioral and institutional equations (for more information, one should read the work of Krishna and Scott (2005), „Keynesian Theory and the AD-AS Framework: A Reconsideration”).

The analysis framework AD-AS derives from the Hicks model (1937) IS-LM and takes into consideration a closed economy, excluding from gross GDP equation the net export ( $N x$ or the difference between exports and imports).

Another reason for which this pattern of analysis was preferred is the fact that - as we analysed in one of our previous works - the Romanian economy and the households have a functioning tendency which has rather a connection with the way described by Keynes and effects of the Ricardian equivalence cannot be identified. This conclusion was the result of the estimations of an econometric model, rolled on a sample of 32 quarterly observations, between 2004 and 2012 (Belingher \& Moroianu, 2015).

This current paper started based on the idea that, in case of a potential economic recession triggered by the sanitary crises, the economic crises have been determined by the response reactions, aimed to limit the spread of the SARS-CoV-2 virus and to cure the patients affected the COVID19 pandemic. The Romanian economy would be affected even in a second stage, at the return moment to consumption, after the lockdown and restrictions phases, when consumption is exhausted and lacking inertia. Therefore, we would like to offer to the decision-makers in macroeconomic politics some guiding lines, based on a sectoral analysis, which could be taken into consideration as support in grounding some budgetary decisions

Specifically, we set out to observe the evolution of the expenditures from the state budget with the staff in public administration and the household consumption dynamics in the Romanian economy. Household consumption (C) represents the main element of the aggregate demand and is the first to react in front of an exogenous shock, such as the one produced by the pandemic. The need for such analysis came precisely from the process of enhancing the budgetary imbalance, as a result of redirecting the existent resources and the incomes towards the medical system.

The budgetary deficit in Romania at the end of 2020 was $9.8 \%$ of GDP. By the end of 2021, the last budget amending in September was built on a target of a budgetary deficit of 7.13\% of GDP. 


\section{THE EVOLUTION OF THE PUBLIC EXPENDITURE IN 2018 AND 2019 AMONG THE MEMBER STATES AND THE NUMBER OF EMPLOYEES IN ROMANIAN PUBLIC ADMINISTRATION}

In 2018 and 2019 the average of the public expenditure as a share of GDP for the EU-28 zone was around 46\% (45.7\% for 2018 and $45.8 \%$ for 2019, as shown in figure 1). By following the evolution of this macroeconomic indicator, it can be noticed that the country which spent most as part of the GDP (55.6\% in 2019) is France, closely followed by Belgium and the Scandinavian countries. Lower down in this top, the states which spent the least from the state budget as a share of GDP are Ireland, Switzerland, and Lithuania. Among these, Ireland has by far the lowest percentage, the level of public expenditure being $24.5 \%$ in 2019.

Ranking fourth in this top, in ascending order, Romania registered values of $34.9 \%$ in 2018 and $36.1 \%$ in 2019 . This was before the pandemic started. We have to mention this fact because after the sanitary crisis this percentage increased in 2020 for all member states. The situation for 2018 and 2019, at the European level, is displayed within the chart below (figure 1) the evolution of the public expenditure calculated as the share of GDP, at the European level for 2018 and 2019.

\section{The evolution of the public expenditure in Europe (\%GDP)}

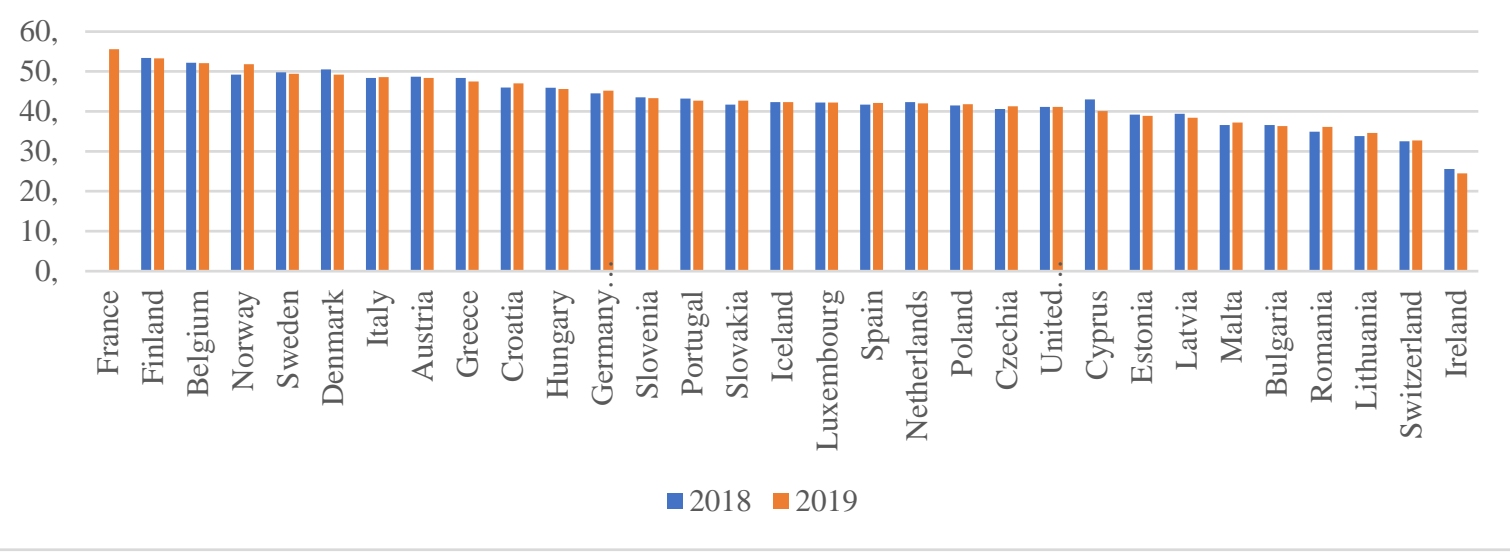

Figure 1. The evolution of the public expenditure in Europe (\% GDP) Source of processed data: Eurostat

Further, the research aims to presents the human resources situation in Romania. It is about employees completely paid from the national state budget. This statistical data reveal radiography closer to reality regarding the direction of this public expenditure and the connection between these and the aggregate demand at the level of the Romanian economy. 2009 was the year during which the highest average number of employees in public administration and defence was registered, according to the data provided by NIS - about 225,000 employees.

In the following years, till 2012, the average number reached 188,000 employees and increased year after year until 2019, when 206,000 persons were employed in public administration and 
defense. We consider that the reduction of the average number of employees registered during the first timeframe (2009-2012) was caused by the austerity measures which had as objective to counterbalance the effects of the economic crises and to balance the state budget. Thus, in 2010 it has been decided to reduce by $25 \%$ the salaries of the employees paid from public funding, as well as to reduce the pensions by $15 \%$. More, the agreement with the International Monetary Fund provided the reduction of the wage and salary bill from 9\% of GDP in 2009 to $7 \%$ in 2015. The graphic evolution of the average number of employees in public administration and defence is presented in the chart below (figure 2) the number of employees in public administration and defence.

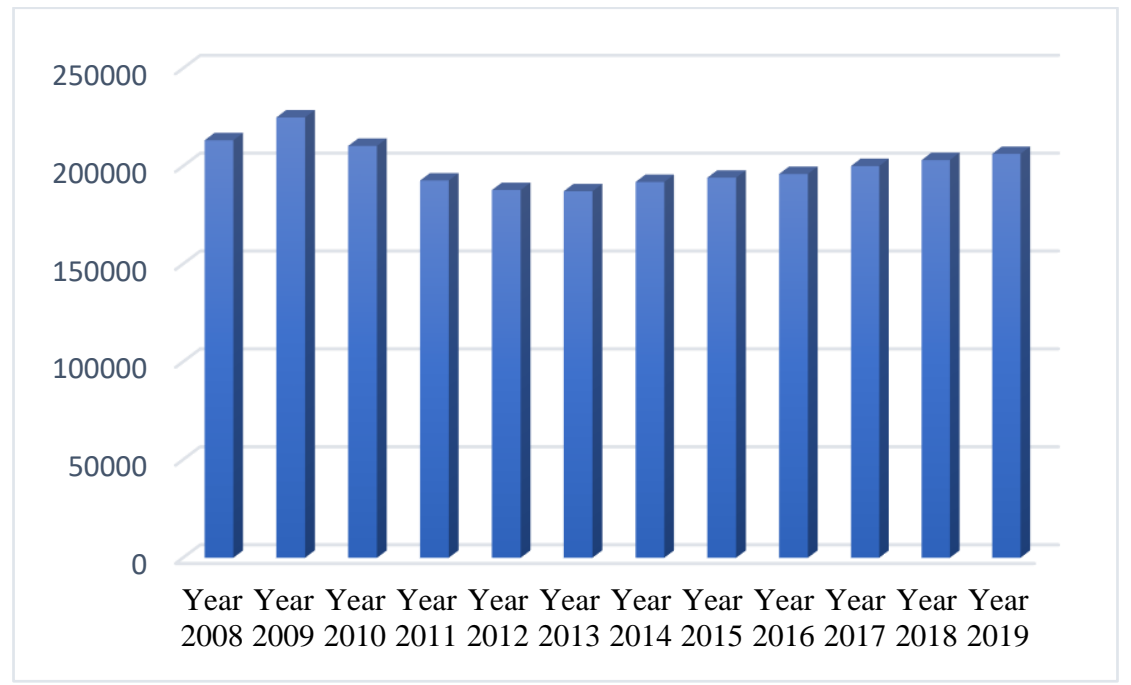

Figure 2. The number of employees in public administration and defense (RO) Source of processed data: National Institute of Statistics

Additionally, the share of these employees out of the total workforce is shown in figure no.3. Similar to the previous chart, between 2009 and 2010 the persons employed in public administration and defence represented about $5 \%$ out of the total workforce - and here certainly we refer to the employees found in the white zone of economy and registered by the official statistics.

After 2010, the share of these employees out of the total workforce has gradually decreased till 2019 with approximately 1\%, the value registered after was almost equal with $4 \%(3,99 \%$ in the last year of the time series above - figure 3 ).

Even if the share of public expenditure in GDP represents in 2018 and 2019 almost one third of the GDP, compared with other states where it represents almost a half, a reduction of these public expenditure would not lead to an increase of the GDP. Reduction of these incomes would lead to a reduction of the demand of consumption, which will actually mean a boost for an additional contraction of the aggregate demand. 


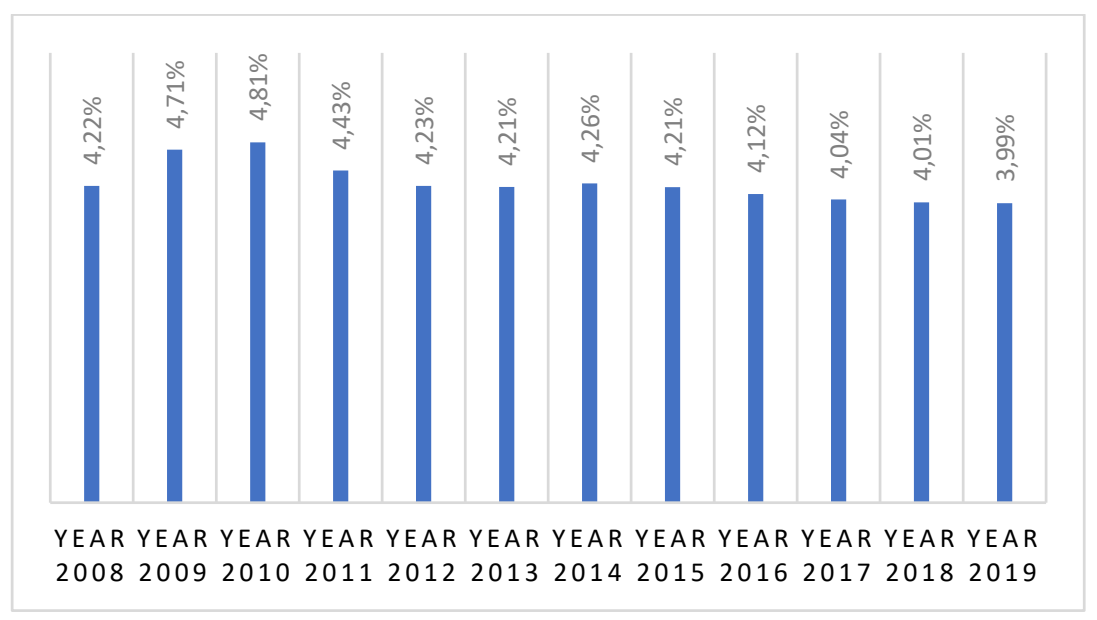

Fgure 3. The share of employees in public admnistration and defence out of the total workforce

Source of processed data: National Institute of Statistics

\section{THE SHOCK FELT BY THE AGGREGATE DEMAND AFTER THE OUTBREAK OF THE PANDEMIC (THE ROMANIAN CASE)}

According to the information provided by media, based on the data received from the Employers' Association of Hotels and Restaurants in Romania, at mid 2020 the year by year decrease of the turnover of this business sector was of about $70 \%$ and the estimation was that $40 \%$ of the employers closed their business. The statistics of the Ministry of Labour show a number of 170,000 employees registered in this sector, but besides them about 130,000 employees are indirectly involved in the activity of the sector. It seems that about 40,000 employees do not work anymore in hospitality business sector, as a result of the pandemic effects (October 2020, https://stirileprotv.ro/stiri/interviurile-lui-vitalie/interviu-cu-antreprenorul-dragos-petrescu-catde-afectata-este-industria-horeca-de-pandemia-de-coronavirus.html). To conclude, a total of 300,000 persons have been affected during 2020 by the close of the restaurants and diminishing the hotels activity.

In June 2020, as a result of the data published by the National Institute of Statistics regarding the tourism activity on the Romanian territory, the arrivals in the accommodation touristic locations dropped by $74,5 \%$, while the tourism nights/nights spent dropped by $77 \%$, compared with the same period of the previous year (YoY). If we look at the distribution of the origin countries, $96 \%$ of the tourists were from Romania and 4\% came from other countries. Also, another business sector connected to $\mathrm{HoReCa} /$ hospitality, which was severely affected by the evolution of the events in 2020, was transport, both transports for goods and for persons. This is evidenced by the total number of the Romanian visitors registered at the border points, which was about 50\% lower, as compared to 2019 (as follows, figure 4 displays the evolution of the number of employees $\mathrm{HoReCa}$ sector in 2020). 


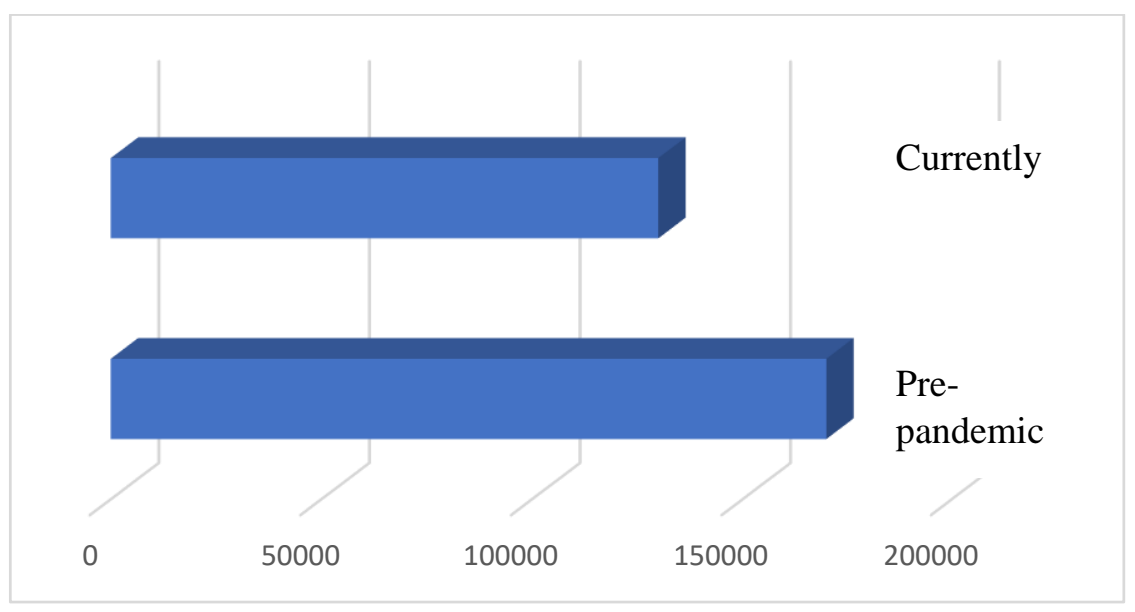

Figure 4. Total direct employees HoReCa before the pandemic

\section{Source: data available in media}

Further to an experimental research (the complete research can be accessed through the following link: https://insse.ro/cms/sites/default/files/cercetare_impactul_covid-19_asupra_mediului_economic.pdf) communicated to the public opinion in April 2020, realised by the same public institution, the National Institute of Statistics, which targeted the estimation of the impact of Covid19 on the economic activity, it came out that the most serious effect of the pandemic (till that moment) was represented by the high grade of uncertainty in economy with regard to the future of the existing businesses in that moment. As NSI communicated, the most affected business sectors, fearing for future were: car manufacturing, other vehicle manufacturing, electric devices manufacturing, metal construction and metal products industry, metallurgical industry. Regarding construction business sector, $61.4 \%$ of the economic agents who were able to estimate the evolution of their volume of activity considered in April 2020 that a reduction of the activity by maximum $25 \%$ was imminent.

According to Smartbill barometer, which measures in real time the evolution of the SMEs activity, we found that most of the business sectors have been affected during the pandemic, both during the first months of lockdown and in the following period, when the restrictions were more relaxed. The statistical data have been collected from a sample of 2000 companies, Smartbill subscribers, between 2019 till present. The evolution by sectors of business activity is presented through figure 5, for the month of August (2020 August vs. August of the previous year - YoY). 


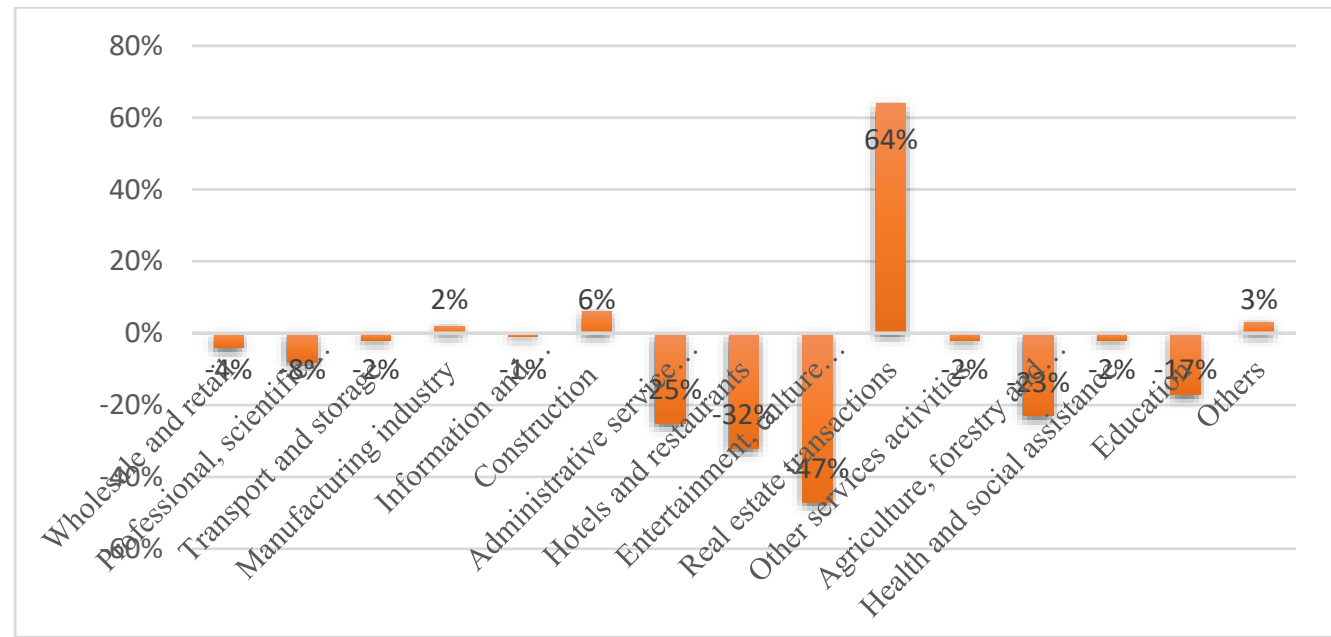

Figure 5. The evolution of SMEs activity by business sectors - August 2020 vs. August 2019 Source of the processed data: Smartbill.ro

It is to be noticed that in the sample of analysed companies, the only sectors which registered positive evolutions from one year to another were: processing industry - a very small increase of $2 \%$; constructions - an increase of 6\% (against all odds registered by NSI research); and the highest increase was recorded for the real estate transactions sector - about $65 \%$.

For the two correlated business sectors which had a positive evolution, i.e. the constructions and the real estate transactions, we identified the following explanations: a number of buildings under construction which were almost completed, have been eventually finalised, especially in this context of uncertainty; and the real estate developers who dealt with real estate complexes (mainly houses), found a powerful incentive in the pandemic, as a result of new created needs for a certain part of population: the need to have a property with an outdoor side (yard). This argument was clearly revealed by the evolution of the real estate transactions sector. At the opposite side, showing the highest decrees of activity, are the SMEs operating in: administrative services ($25 \%$ ), of course HoReCa/hospitality (-32\%) and the steepest drop was noticed among the SMEs dealing with entertainment, culture and recreational business. Even if the pandemic sped up the digitalisation process for many private and public entities, can be noticed that even IT and Communication sector registered 1\% drop in August 2020, compared with August in the previous year.

According to the data provided by the World Bank, the Romanian gross GDP dropped in 2020 by $3.9 \%$. Split by sectors of activity, this drop should be the result of a $9.1 \%$ decrease in industry, $21.2 \%$ decrease in agriculture, forestry and fishing, and a 2\% drop in services. More, in 2020 the unemployment rate was situated around the $5 \%$ threshold, calculated as a percentage change vs. the same period of the previous year. Regarding the private consumption, this macroeconomic aggregate slightly increased with approximately $2.7 \%$, according to the National Institute of Statistics - this was considered a rebound after the lockdown period, at the beginning of 2020. Even with this slight increase, a part of it might have been caused by the inflationary pressures, felt across EU - so, the increase of consumption might be an artificial process. 
Thus, as a result of presenting statistical data in this section, the shock felt by the aggregate demand in the Romanian economy is revealed. Showed in a chart, based on the model type AD-AS, the impact of COVID-19 pandemic upon the aggregate demand is represented as follows:

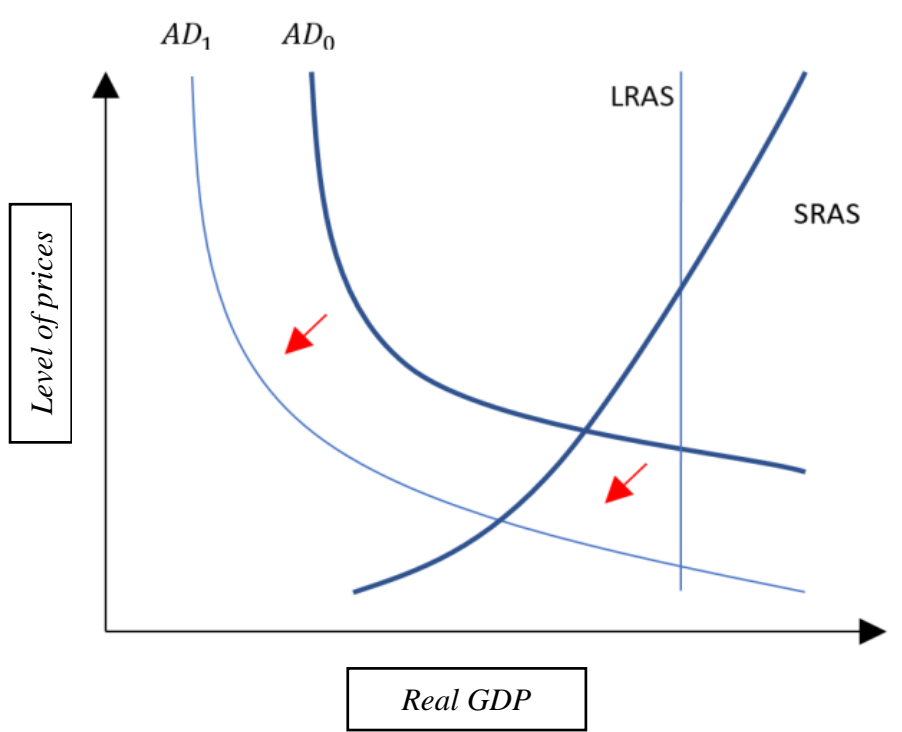

Figure 7. The Impact of COVID 19 Pandemic upon the Aggregate Demand Source: Authors, according to the related specific literature

The impact of Covid-19 pandemic upon the curve of the aggregate demand, where AD curve represents the curve of the short term aggregate demand, while SRAS and LRAS curves are the graphical representations of the short term and long term aggregate supply. It can be observed in above chart that the curve of the aggregate demand is pushed towards left, compared with the previous position; this change in position reflects a reduction of this macroeconomic variable.

\section{CONCLUDING REMARKS}

As it has been demonstrated by Daniel Kahneman and Amos Tversky, the negative emotional impact of loss is felt twice more powerful then the positive impact of the earnings; thus, there is a tendency for the governors - fuelled by the necessity of populist political messages - that during crisis periods to adjust the public expenditure, mainly the salaries of the State employees, as a response to the budgetary constraints. However, in such situation, affecting this category of employees would lead to the increase and exacerbation of the problems created by the sanitary crisis. A reduction of the expenses related to this category of employees would have meant an impact on the level of consumption, in the sense of amplification the contraction of the aggregate demand. To maintain a certain level of consumption, induce a demand for the precursors of production, where it is necessary to achieve that demand, meaning that the existing demand generates another demand. 
Given that the aggregate demand was abruptly forced to shrink as a result of the measures regarding social distancing, an extra reduction of the aggregate demand, generated by budgetary constraints, could have lead to an economic collapse. Thus, in order not to reach an economic disaster, UE decision makers had the wisdom to give up UEM restriction, which said that the yearly budgetary deficit to be not higher than $3 \%$ of GDP (especially in the conditions of the year 2020, when the GDP is contracting).

To maintain the incomes/wages for this category of government employees, should be perceived in the same way as the aids offered to those deeply affected by the measures aimed to limit the virus spread, in order to keep them in business. The consumption generated by them is actually a stabiliser, a protection element to avoid the consumption collapse, during difficult times.

To the extent that, at a certain moment, this works will be read by the government economic decision-makers, facing similar situations, it would be recommended that part of the incomes paid to the public administration to be converted into/paid as vouchers, with the objective to support those affected by the pandemic (for instance, meal tickets to not be used in the shops selling food products, but only in the shops/restaurants selling cooked food).

\section{REFERENCES:}

Belingher, D. \& Moroianu, N. (2015). Empirical evidence on the Ricardian Equivalence in Romania. Theoretical and Applied Economics. Volume XXII, No. 2(603), 163-170.

Colander, D. (1992). New Keynesian Economics in Perspective. Eastern Economic Journal. 18(4), 437-448.

Friedman, M. (1953). The Methodology of Positive Economics. In Essays in Positive Economics. Chicago University of Chicago Press.

Hicks, J. R. (1937). Mr. Keynes and the "Classics", A Suggested Interpretation. Econometrica, 5(2), 147-159.

Klein, L. (1944). The Keynesian Revolution. London: Editura Palgrave Macmillan.

Krishna, A. \& Skott, P. (2005). Keynesian Theory and the AD-AS Framework: A Reconsideration. Economics Department Working Paper. Series 47.

Lucas, R. (1976) Econometric Policy Evaluation: A Critique. Carnegie-Rochester Conference Series on Public Policy. Vol 1, 19-46.

National Institute of Statistics. (2020). Press release no. 104, 15 April 2020.

Taleb, N. N. (2018). The Black Swan - The Impact of the Highly Improbable. Third Edition Revised. Bucharest: Curtea Veche Publishing.

Tempelman, J.H. (2010). Austrian Business Cycle Theory and the Global Financial Crisis: Confessions of a Mainstream Economist. The Quarterly Journal of Austrian Economics. 13(1), 3-15.

Stiglitz, J. E. \& Walsh, C. E. (2002). Economics, Third edition. New York: Norton, W. W. \& Company, Inc. 